\title{
PERCEIVED PRICE AS ANTECEDENT OF SATISFACTION AND LOYALTY: LEARN FROM FAST FOOD INTERNATIONAL RESTAURANTS
}

\author{
Syah, T. Y. R., Alimwidodo, P. C., Lianti, L., Hatta, H.
}

Tantri Yanuar Rahmat Syah / University of Esa Unggul, Faculty of Management, Department of Economics and Business, Jalan Arjuna Utara No.9, Kebon Jeruk, West Jakarta 11510, Indonesia. Email: tantri.yanuar@esaunggul.ac.id

Patrick Christian Alimwidodo / University of Esa Unggul, Faculty of Management, Department of Economics and Business, Jalan Arjuna Utara No.9, Kebon Jeruk, West Jakarta 11510, Indonesia. Email: patrickchristian97@student.esaunggul.ac.id

Lovinda Lianti / University of Esa Unggul, Faculty of Management, Department of Economics and Business, Jalan Arjuna Utara No.9, Kebon Jeruk, West Jakarta 11510, Indonesia. Email: lovindakim@student.esaunggul.ac.id

Holila Hatta / University of Bakrie, Faculty of Management, Department of Management, Jalan H.R Rasuna Said Kav C-22, Kuningan, South Jakarta, Indonesia. Email: holila.hatta@bakrie.ac.id

\section{Abstract}

Currently, multinational fast-food restaurant like the American fast food restaurant business is in great demand in Asian countries, especially in Indonesia. Maybe it can be categorised as a trend that is currently in effect. The uniqueness of the presentation or product appearance, the various types of menus and tastes, the restaurant environment, the prices offered, and several other factors contribute to creating the purchase intention of Indonesian customers. However, it is still rare to use this concept of thinking as the basic basis for measuring customer satisfaction, especially in American fast food restaurant branches in Asia, especially in Indonesia. Based on this explanation, the purpose of this study is to determine the relationship between product quality, service quality, physical environment quality, perceived price, satisfaction, loyalty, happiness, and trust in the customers of the fastfood restaurant. We distributed online questionnaires via google with a purposeful sampling method to 130 respondents conducted in July 2021. This study uses the SEM analysis method. The results show that there is a relationship between perceived price, product quality, service quality, physical environment quality, and customer satisfaction. Customer satisfaction has a positive effect on loyalty and happiness. Trust can moderate the relationship between customer satisfaction and loyalty. The results can be applied by fastfood restaurants that are interested in learning about similar factors that can increase customer satisfaction and loyalty, especially in developing countries that have almost the same respondent criteria as Indonesia.

Implications for Central European audience: The knowledge used in various marketing studies that support customer satisfaction and customer loyalty can be built on the quality they receive and their perception of the price of the product. Also noteworthy is the finding that the effect of product quality and service quality does not always affect each product category. These results can be utilised by fast-food restaurant businessmen and other 
culinary businesses who use foreign themes to increase competitiveness in the country. But it can also be used for European producers who want to open their culinary business in Asian countries.

Keywords: customer satisfaction; loyalty; fast-food restaurant JEL Classification: M31, G21

\section{Introduction}

Customer satisfaction and loyalty have become important issues in management, especially for marketing, and this will continue to develop (Ryu \& Han, 2010; Hanaysha, 2016). There is some sufficient evidence to explain that customer satisfaction and loyalty are related to service quality and will lead to the high profitability of a business (Rahman, 2013). Customer satisfaction is a key factor for long-term business resilience and business reputation (Gong \& Yi, 2018; Syah \& Wijoyo, 2021). Customer satisfaction occurs after the customer compares the expectations of a product with the products consumed (Hamzah et al., 2021). MösleinTröppner et al. (2020) argue that customer satisfaction can only make customers loyal to one particular company if the company does not have competitors who provide better offers such as quality, price, and service.

Rahman (2013) states that it is very important for a company to provide the best quality service to customers in today's business environment because of the very tight competition in the market. The service quality of a good product can create satisfaction for its customers (Zhong \& Moon, 2020; Elizar et al., 2020). Furthermore, Rothenberger (2015) and AlMsallam (2015) explain that customer satisfaction can be measured by assessing prices and the brand image of a product. In addition, customers' perception of the price of the product can influence their decision to make a purchase (Möslein-Tröppner et al., 2020). When customers are satisfied with the product they bought, they will always want to come back to buy the product without comparing it again with competing products (Paramartha \& Syah, 2020).

Generally, almost all organisations try to be able to meet the needs, expectations and desires of their customers in order to be able to continue to make them satisfied and loyal (Kamrul Islam Shaon \& Rahman, 2015). Rothenberger (2015) and Zhuang and Jiang (2016) suggest that every company or organisation also pays attention to the quality of its products. This can create customer satisfaction and make them want to continue to repurchase the product. Previous studies have proven that product quality plays an important role in building customer satisfaction (Yu \& Fang, 2009; Fandos-Roig et al., 2020). Ryu and Han (2010) added the quality of the physical environment as one of the determinants of customer satisfaction. The results of Rothenberger (2015), Al-Msallam (2015), Zhuang and Jiang (2016) and Hanaysha (2016) also concluded that the quality of the physical environment has a significant positive effect on customer satisfaction.

The highest level of satisfaction for customers is their happiness (Zhong \& Moon, 2020). Similar to this statement, Sweeney et al. (2015) also said that satisfaction in daily life would be able to trigger its own happiness in the individual. According to Zhong and Moon (2020), the happiness felt by customers is able to create their satisfaction and loyalty to the product 
they are using. In addition to the several factors previously described, Alkhurshan and Rjoub (2020) mention that there are other factors that also play a role in shaping customer loyalty, is trust.

The development of fast-food restaurants owned by foreign countries is growing rapidly in Indonesia. There are at least five big international fast-food restaurants in Indonesia, such as KFC, McD, Pizza Hut, Dunkin' Donuts, and Hoka Hoka Bento. From this, it can be seen that the USA and Japan fast food restaurants dominate, compared to European fast-food restaurants in Indonesia. The tendency of local people who like to use or consume foreign products is one of the factors that influence it, not least in the field of fast-food restaurants. For this reason, many entrepreneurs in this field are increasingly competitive in competing to maintain and increase the number of customers and maintain business continuity. To achieve this, these business people must pay attention and are required to be able to obtain and improve customer satisfaction and loyalty on an ongoing basis.

In addition, fast food restaurant business players belonging to foreign countries also need to consider the price of each product or menu offered. Even though Indonesians like to use foreign products, they still look at the prices of these products, especially during this pandemic. The COVID-19 pandemic has made all countries, including Indonesia experience disruptions in economic conditions. This has made the Indonesian people more sensitive to prices. There is a possibility that they will switch to restaurants that provide affordable prices rather than just following the prevailing trend.

This study aims to determine the factors that influence customer satisfaction and loyalty at three international fast-food restaurants (KFC, McD, and Pizza Hut) in Indonesia. It is assumed that service quality, product quality, physical environment quality, perceived price, trust, and happiness are determinants of customer satisfaction and loyalty levels, which allow them to be used as scientific references in the marketing field, especially in the culinary business. Furthermore, the results of this study are intended to help international fast food restaurant business players understand several factors that can make this business grow in Asia.

\section{Theoretical framework and hypotheses}

\section{Perceived price, product quality, service quality, physical environment quality, and customer satisfaction}

Customer satisfaction is influenced by price perception and indirectly by perceived price (Dalati \& Al Hamwi, 2016). Perceived price is very important for customer satisfaction because service is always evaluated by the customer based on the price (Al-Msallam, 2015). Customers judge prices based on the value of the product they have felt (Tröppner et al., 2020). Acceptable and reasonable price has become the basis of valuing by the customer of perceived price (Dalati \& Al Hamwi, 2016). Rothenberger (2015) explains that perceived price can affect negative perception, unsatisfaction of customer, decreasing repurchased behaviour, negative assumption and complaints. Improved and recommended perceived price has a great impact on customer satisfaction (Dalati \& Al Hamwi, 2016).

In terms of defining satisfaction and customer loyalty, product quality is very important (Zhong \& Moon, 2020). Altamore et al. (2018) stated that customer perception of a product shade and service has closely affected their emotion, whether positive or negative, and the intention 
of behaviour based on experience in a restaurant. Good and friendly quality service can make the customer satisfied (Mulyo et al., 2021). The high-quality service can make the user of the service feel satisfied (Mulyo et al., 2021). Expected quality by the customer is evaluated using an attribute in measuring food quality, service quality and physical environment quality (Zhang et al., 2019). Food, service and physical environment are factors for satisfaction food experience to customers (Bilgihan et al., 2018). Altamore et al. (2018) prove that product quality can influence customer satisfaction. Based on that Literature, then hypotheses proposed as follows:

H1: The perceived price has a positive influence on customer satisfaction.

H2: Product quality has a positive influence on customer satisfaction.

H3: Service quality has a positive influence on customer satisfaction.

H4: Physical environment quality has a positive influence on customer satisfaction.

\subsection{Perceived price, service quality, and physical environment quality}

The amount of money spent and felt by the customer becomes the price basis on product and service (Zhong \& Moon, 2020). According to Yi et al. (2018), perceived price does not increase the quality of a product or service, but it can influence subjective value. Zhong and Moon (2020) stated that even though the perceived price of the customer can change their expectation on product quality, service, and environment of a restaurant, there is still a small number of research-tested how perceived price influences the evaluation of customers on the restaurant quality, the relation between perceived price and quality. Based on the explanation, then the hypotheses proposed are as follows:

H5: The perceived price has a positive influence on product quality.

H6: The perceived price has a positive influence on service quality.

H7: The perceived price has a positive influence on physical environment quality.

\subsection{Trust, customer satisfaction, customer loyalty, and happiness}

Customer satisfaction is defined as an evaluation of a product or service based on buying experience and consumption from time to time. Rahman (2013) said that customer satisfaction plays an important role in the formation of customer loyalty. Customer loyalty can be seen as a customer's commitment to dealing with a particular product and buying its products and services (Kamrul Islam Shaon \& Rahman, 2015). According to Zhong and Moon (2020), service quality and product, price strategy, and store characteristics are the main factors to influence customer satisfaction. Satisfied customers tend to re-visite to buy the product and become loyal customers; they tend to give a recommendation to other customers and disregard the price. While according to Altamore et al. (2018), customer experience can't be correlated with functional dimensions and other dimensions such as physical aspect, emotional, cognitive, behaviour and relation. While food consumption in an extraordinary not only can make the customer satisfied but also happy (Zhong \& Moon, 2020).

Alexander (2010) and Zhong and Moon (2020) said that happiness is a high level of satisfaction. Satisfaction followed by related activity in life can increase customer happiness 
(Sweeney et al., 2015). Happiness can make customers satisfied and become more loyal, but no research has yet in testing whether happiness has a role in satisfaction and loyalty. Therefore, the relations between these factors are not certain (Zhong \& Moon, 2020). Moreover, trust also has an influence on customer loyalty (Alkhurshan \& Rjoub, 2020). It is important to every brand to gain trust from the consumer and receive loyalty and decrease risk to change the brand (Fandos-Roig et al., 2020; Sarmiento-Guede et al., 2021). Trust and diversion of struggle have important roles in determining the level of customer loyalty (Alkhurshan \& Rjoub, 2020). Some researches prove that trust has a positive influence on customer loyalty (Alkhurshan \& Rjoub, 2020; Hamzah et al., 2021). Based on the explanation above, then the hypotheses proposed are as follows:

H8a: Customer satisfaction has a positive influence on customer loyalty.

H8b: Moderated trust has a positive influence on customer satisfaction and customer loyalty.

H9: Customer satisfaction has a positive influence on happiness.

\section{Figure 1 | Conceptual model}

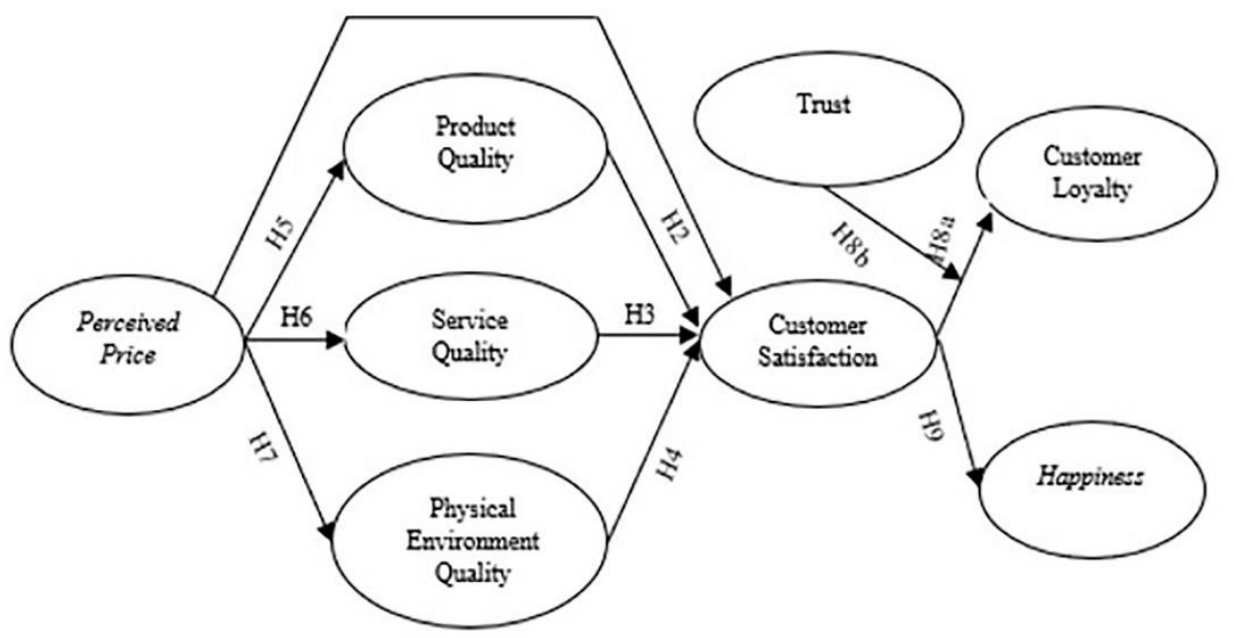

Source: authors' own elaboration

The conceptual model is based on the relationship between variables, and the development of the hypotheses discussed earlier.

\section{Research methodology}

The research method consists of several parts, including research design, measuring instruments, population and samples, and data analysis techniques. Several factors that will be examined are product quality, service quality, physical environment quality, perceived price, trust, and happiness. Some of these factors are expected to be able to influence customer satisfaction and customer loyalty of international fast-food restaurants in Indonesia. 


\subsection{Research design}

This study is deductive in nature with the aim of examining the factors that influence customer satisfaction and loyalty in international fast-food restaurants in Indonesia. This study uses hypothesis testing based on the research model that has been developed in the conceptual model. Hypothesis testing in this study explains the relationship between the independent variable and the dependent variable. Finally, the data collection used a purposive sampling method by distributing online questionnaires through google form to collect the information we needed.

\subsection{Measuring instruments}

Data gathering of the research is using a survey method with an online questionnaire. The measurement is using 5-item Likert scale, where score one means very disagree (STS), score two means disagree (TS), score three Neutral (N), score four means Agree (S), score five means Strongly Agree (SS). Perceived price variable measurement adopted from Hanaysha (2016) and Han and Kim (2009) comprises of 3 questions. Product quality variable measurement adopted from Yu and Fang (2009) comprises of 3 questions. Service quality variable measurement adopted from Ryu et al. (2012) and Qin and Prybutok (2009) comprises of 4 questions. Physical environment quality variable measurement adopted from Ryu et al. (2012) and Hanaysha (2016) comprises of 3 questions. While customer satisfaction variable measurement also adopted from Ryu et al. (2012) and Hanaysha (2016) comprises of 3 questions. Customer loyalty variable measurement adopted from CuestaValiño et al. (2021) comprises of 3 questions. Happiness variable measurement was adopted from Gong and Yi (2018) consist of 3 questions. Trust variable measurement adopted from Cuesta-Valiño et al. (2021) comprises of 4 questions. The total statements in the questionnaire that we used were 26 items.

\subsection{Population and samples}

Population in this research is the buyers of fast-food (KFC, McD, and Pizza Hut) in Indonesia that have the age of 20 to 30 years old with the expense per month for consumption of 1 to 4 million rupiahs that the research is done in July 2021 during COVID-19 pandemic, with minimum 1time purchase of product from one of a fast-food restaurant (Ryu et al., 2012). We use 130 respondents in this study.

\subsection{Data analysis techniques}

To check the content validity and accuracy of the questions and their measures, we conducted qualitative pre-tests before formally collecting data. We first conducted a quantitative pre-test on 30 fast-food restaurant customers by distributing surveys on several popular mobile social media applications in Indonesia, such as WhatsApp and Telegram. After the pre-test, we distributed the questionnaire among fast-food restaurant customers in Indonesia. Data collection was in July 2021, and 130 valid responses were received in one week. All respondents met the required criteria, such as having purchased a product from a fast-food restaurant at least once.

Measuring validity can be done with the measurement model in the CFA. CFA is a measurement model for indicators that represent a factor. The measurement model describes how the latent factor is measured. The relationship between the latent factor and 
its indicators is indicated by the direction of the arrow starting from the latent factor towards the indicators that represent it (Hair et al., 2009). To test the validity of the used questionnaire questions, we use factor analysis SPSS by seeing the value listed in Kaiser Meyer-Olkin (KMO) and Measure of Sampling Adequacy (MSA). If the value of KMO and MSA is higher than 0.5 , then factor analysis is suitable. Then, to test the reliability of the used questionnaire questions is using Cronbach's Alpha. In which the value of Cronbach's Alpha the better it is (Hair et al., 2009).

Furthermore, we used Structural Equation Model (SEM)-Lisrel to process and analyse data in this research. SEM Lisrel is used to confirm whether the hypothesis that is built is supported or not by the data received. This is in accordance with what Hair et al. (2009) said that Structural Equation Modeling (SEM) is a multivariate technique that combines aspects of multiple regression (examining dependency relationships). To measure the validity of the indicator of the variable, it can be seen the value of 'Loading Factor' or 'Standardized Loading Estimate' $>0.05$ on the results of SEM Lisrel output (Hair et al., 2009). After that, the next step is to test the reliability of the data used by indicators based on the variance Extracted (VE) and Construct Reliability (CR) formulas. For construct reliability, the minimum limit value is $\geq 0.70$, while for the variance extracted, the minimum limit value is $\geq 0.50$ (Hair et al., 2009).

The formula used to calculate construct reliability is:

$$
\text { Construct Reliability }=\frac{\left(\sum \text { standarized loading }\right)^{2}}{(\Sigma \text { standarized loading })^{2}+\sum \varepsilon j}
$$

The formula used to calculate variance extracted is:

$$
\text { Variance extracted }=\frac{\sum \text { standarized loading }}{2}
$$

Description:

- Standardised loading is obtained directly from standardised loading for each indicator.

- $\quad \sum \varepsilon j$ is total error $=1-(\text { standardised loading })^{2}$

To measure how well the proposed model reproduces the observed data and provide the most basic assessment of how well the researcher's theory fits into the sample data, we can look at the Goodness of Fit value in SEM-Lisrel output (Hu \& Bentler, 1999; Lai, 2018).

\section{Data analysis and results}

\subsection{Respondent's demographic}

Table 1 presents the demographic information of the 130 respondents who completed the questionnaire. The sample was quite balanced in terms of sex $(27.69 \%$ males, $72.31 \%$ females), terms of age (6.16\% less than 20 years old, $64.61 \%$ around 21 to 30 years old, and as many as $29.23 \%$ more than 30 years old), based on criteria of consumption expenses a month $(24.62 \%$ less than 600,000 IDR, $16.92 \%$ with the range of $600,000-1,000,000$ IDR, $17.69 \%$ with the range of $1,000,000-1,800,000$ IDR, $19.23 \%$ with the range of $1,800,000$ - 
3,000,000 IDR, 21.54\% above 3,000,000 IDR), and terms of fast-food restaurant $(37.70 \%$ chose KFC, $50.77 \%$ chose McD, $11.53 \%$ chose Pizza Hut).

Table 1 | Respondent's demographic

\begin{tabular}{|c|c|c|}
\hline Gender & Number & $\%$ \\
\hline Male & 36 & $27.69 \%$ \\
\hline Female & 94 & $72.31 \%$ \\
\hline Total & 130 & $100 \%$ \\
\hline Age & Number & $\%$ \\
\hline$<20$ years old & 8 & $6.16 \%$ \\
\hline $21-30$ years old & 84 & $64.61 \%$ \\
\hline$>30$ years old & 38 & $29.23 \%$ \\
\hline Total & 130 & $100 \%$ \\
\hline Criteria of consumption expenses a month & Number & $\%$ \\
\hline$<600,000$ (IDR) & 32 & $24.62 \%$ \\
\hline $600,000-1,000,000$ (IDR) & 22 & $16.92 \%$ \\
\hline $1,000,000-1,800,000$ (IDR) & 23 & $17.69 \%$ \\
\hline $1,800,000-3,000,000$ (IDR) & 25 & $19.23 \%$ \\
\hline$>3,000,000$ (IDR) & 28 & $21.54 \%$ \\
\hline Total & 130 & $100 \%$ \\
\hline Restaurant & Number & $\%$ \\
\hline KFC & 49 & $37.70 \%$ \\
\hline McD & 66 & $50.77 \%$ \\
\hline Pizza Hut & 15 & $11.53 \%$ \\
\hline Total & 130 & $100 \%$ \\
\hline
\end{tabular}

Source: authors' own elaboration

\subsection{Validity and reliability of variable measurement}

From the results of testing the validity and reliability of the measuring instrument for each variable using factor analysis in SPSS, all indicators on the measuring instrument for each variable are declared valid and reliable. Table 2 shows details. 
Table 2 | Validity and reliability of the indicators on each variable

\begin{tabular}{|c|c|c|c|c|c|}
\hline Indicator & Variables & KMO & MSA & $\begin{array}{c}\text { Cronbach's } \\
\text { Alpha }\end{array}$ & Description \\
\hline PP1 & \multirow{3}{*}{$\begin{array}{l}\text { Perceived } \\
\text { Price }\end{array}$} & \multirow{3}{*}{0.710} & 0.673 & \multirow{3}{*}{0.813} & \multirow{3}{*}{ Valid and Reliable } \\
\hline PP2 & & & 0.749 & & \\
\hline PP3 & & & 0.717 & & \\
\hline KP1 & \multirow{3}{*}{$\begin{array}{l}\text { Product } \\
\text { Quality }\end{array}$} & \multirow{3}{*}{0.675} & 0.746 & \multirow{3}{*}{0.796} & \multirow{3}{*}{ Valid and Reliable } \\
\hline KP2 & & & 0.627 & & \\
\hline KP3 & & & 0.680 & & \\
\hline KS1 & \multirow{4}{*}{$\begin{array}{l}\text { Service } \\
\text { Quality }\end{array}$} & \multirow{4}{*}{0.825} & 0.826 & \multirow{4}{*}{0.911} & \multirow{4}{*}{ Valid and Reliable } \\
\hline KS2 & & & & & \\
\hline KS3 & & & 0.834 & & \\
\hline KS4 & & & 0.842 & & \\
\hline KLF1 & \multirow{3}{*}{$\begin{array}{c}\text { Physical } \\
\text { Environment } \\
\text { Quality }\end{array}$} & \multirow{3}{*}{0.693} & 0.751 & \multirow{3}{*}{0.817} & \multirow{3}{*}{ Valid and Reliable } \\
\hline KLF2 & & & 0.646 & & \\
\hline KLF3 & & & 0.704 & & \\
\hline KPP1 & \multirow{3}{*}{$\begin{array}{l}\text { Customer } \\
\text { Satisfaction }\end{array}$} & \multirow{3}{*}{0.679} & 0.802 & \multirow{3}{*}{0.843} & \multirow{3}{*}{ Valid and Reliable } \\
\hline KPP2 & & & 0.626 & & \\
\hline KPP3 & & & 0.664 & & \\
\hline LP1 & \multirow{3}{*}{$\begin{array}{l}\text { Customer } \\
\text { Loyalty }\end{array}$} & \multirow{3}{*}{0.604} & 0.582 & \multirow{3}{*}{0.690} & \multirow{3}{*}{ Valid and Reliable } \\
\hline LP2 & & & 0.568 & & \\
\hline LP3 & & & 0.777 & & \\
\hline H1 & \multirow{3}{*}{ Happiness } & \multirow{3}{*}{0.727} & 0.707 & \multirow{3}{*}{0.839} & \multirow{3}{*}{ Valid and Reliable } \\
\hline H2 & & & 0.717 & & \\
\hline H3 & & & 0.761 & & \\
\hline K1 & \multirow{4}{*}{ Trust } & \multirow{4}{*}{0.858} & 0.852 & \multirow{4}{*}{0.973} & \multirow{4}{*}{ Valid and Reliable } \\
\hline K2 & & & 0.872 & & \\
\hline K3 & & & 0.810 & & \\
\hline K4 & & & 0.908 & & \\
\hline
\end{tabular}

Source: authors' own elaboration

All statements were declared valid and reliable. Then we processed all data with SEM to find out whether this data supported or not for the entire hypothesis. The lowest value of validity and reliability is on customer loyalty with 0.690 and the highest on trust with 0.973 . 


\subsection{Structural Equation Model (SEM)}

Before testing our research hypotheses, we studied the measurement model in terms of item and construct reliability and convergent and discriminant validity. First, the factor loadings and descriptive statistics for all items are as shown in Table 2, and the factor loading of most items reaches the 0.5 threshold. The loading factor value can be seen from the standardised solution path diagram. The exceptions are PP in PP1, PP2, PP3; KP in KP1, KP2, KP3; KS in KS1, KS2, KS3, KS4; KLF in KLF1, KLF2, KLF3; KPP in KPP1, KPP2, KPP3; LP in LP1, $\mathrm{LP} 2$, LP3; $\mathrm{H}$ in $\mathrm{H} 1, \mathrm{H} 2, \mathrm{H} 3$, and $\mathrm{K}$ in $\mathrm{K} 1, \mathrm{~K} 2, \mathrm{~K} 3, \mathrm{~K} 4$, although they are still over 0.5 and have suitable construct reliability and validity, as explained below. Second, construct reliability was assessed in terms of co reliability (CR and VE; see Table 3 and Table 4). CR is greater than the 0.7 threshold and VR is greater than 0.5 threshold (Hair et al., 2018), for all constructs and models except for perceived price (PP), construct reliability is 0.60 , variance extracted is 0.33. Overall, the results show that the items and constructs have been measured with an acceptable degree of reliability and validity, similar to most of the empirical research on international marketing.

Table 3 | Construct reliability (CR)

\begin{tabular}{|c|c|c|c|c|c|c|c|}
\hline \multirow[b]{2}{*}{ Indicators } & \multirow[b]{2}{*}{ Variable } & \multirow[b]{2}{*}{$\begin{array}{l}\text { Standard } \\
\text { Loading }\end{array}$} & \multirow[b]{2}{*}{ Error } & \multicolumn{4}{|c|}{ Construct Reliability } \\
\hline & & & & $\begin{array}{l}\sum \text { STd. } \\
\text { Loading }\end{array}$ & $\begin{array}{l}\left(\sum \text { STd. }\right. \\
\text { Loading })^{2}\end{array}$ & $\sum$ Error & $\begin{array}{l}\text { Nilai } \\
\text { CR }\end{array}$ \\
\hline PP1 & \multirow{3}{*}{$\begin{array}{l}\text { Perceived } \\
\text { Price }\end{array}$} & 0.53 & 0.72 & \multirow{3}{*}{1.72} & \multirow{3}{*}{2.96} & \multirow{3}{*}{2.01} & \multirow{3}{*}{0.60} \\
\hline PP2 & & 0.63 & 0.60 & & & & \\
\hline PP3 & & 0.56 & 0.69 & & & & \\
\hline KP1 & \multirow{3}{*}{$\begin{array}{l}\text { Product } \\
\text { Quality }\end{array}$} & 0.70 & 0.51 & \multirow{3}{*}{2.28} & \multirow{3}{*}{5.20} & \multirow{3}{*}{1.24} & \multirow{3}{*}{0.81} \\
\hline KP2 & & 0.83 & 0.30 & & & & \\
\hline KP3 & & 0.75 & 0.43 & & & & \\
\hline KS1 & \multirow{4}{*}{$\begin{array}{l}\text { Service } \\
\text { Quality }\end{array}$} & 0.77 & 0.41 & \multirow{4}{*}{3.30} & \multirow{4}{*}{10.89} & \multirow{4}{*}{1.28} & \multirow{4}{*}{0.89} \\
\hline KS2 & & 0.81 & 0.34 & & & & \\
\hline KS3 & & 0.84 & 0.30 & & & & \\
\hline KS4 & & 0.88 & 0.23 & & & & \\
\hline KLF1 & \multirow{3}{*}{$\begin{array}{c}\text { Physical } \\
\text { Environment } \\
\text { Quality }\end{array}$} & 0.69 & 0.53 & \multirow{3}{*}{2.27} & \multirow{3}{*}{5.15} & \multirow{3}{*}{1.29} & \multirow{3}{*}{0.80} \\
\hline KLF2 & & 0.79 & 0.38 & & & & \\
\hline KLF3 & & 0.79 & 0.38 & & & & \\
\hline KPP1 & \multirow{3}{*}{$\begin{array}{l}\text { Customer } \\
\text { Satisfaction }\end{array}$} & 0.74 & 0.45 & \multirow{3}{*}{2.45} & \multirow{3}{*}{6.00} & \multirow{3}{*}{0.98} & \multirow{3}{*}{0.86} \\
\hline KPP2 & & 0.84 & 0.29 & & & & \\
\hline KPP3 & & 0.87 & 0.24 & & & & \\
\hline LP1 & \multirow{3}{*}{$\begin{array}{l}\text { Customer } \\
\text { Loyalty }\end{array}$} & 0.80 & 0.36 & \multirow{3}{*}{2.19} & \multirow{3}{*}{4.80} & \multirow{3}{*}{1.36} & \\
\hline LP2 & & 0.83 & 0.31 & & & & 0.78 \\
\hline LP3 & & 0.56 & 0.69 & & & & \\
\hline H1 & Hanninesc & 0.91 & 0.18 & 235 & 552 & 114 & 083 \\
\hline $\mathrm{H} 2$ & nappintess & 0.75 & 0.44 & 2.00 & 0.02 & 1.14 & 0.00 \\
\hline
\end{tabular}




$\begin{array}{llllllll}\text { H3 } & & 0.69 & 0.52 & & & & \\ \text { K1 } & & 0.96 & 0.08 & & & & \\ \text { K2 } & \text { Trust } & 0.95 & 0.09 & & & \\ \text { K3 } & & 0.97 & 0.06 & 3.81 & 14.52 & 0.36 & \mathbf{0 . 9 8} \\ \text { K4 } & & 0.93 & 0.13 & & & & \end{array}$

Source: SEM Lisrel

Table 4 | Variance extracted (VE)

\begin{tabular}{|c|c|c|c|c|c|c|}
\hline \multirow[b]{2}{*}{ Indicators } & \multirow[b]{2}{*}{ Variable } & \multirow[b]{2}{*}{$\begin{array}{l}\text { Standard } \\
\text { Loading }\end{array}$} & \multirow[b]{2}{*}{ Error } & \multicolumn{3}{|c|}{ Variance Extracted } \\
\hline & & & & $\begin{array}{l}\text { Standard } \\
\text { Loading }^{2}\end{array}$ & $\sum_{\text {Loading }}^{\sum \text { STd. }}$ & Nilai VE \\
\hline PP1 & \multirow{3}{*}{$\begin{array}{l}\text { Perceived } \\
\text { Price }\end{array}$} & 0.53 & 0.72 & 0.28 & \multirow{3}{*}{0.99} & \multirow{3}{*}{0.33} \\
\hline PP2 & & 0.63 & 0.60 & 0.40 & & \\
\hline PP3 & & 0.56 & 0.69 & 0.31 & & \\
\hline KP1 & \multirow{3}{*}{$\begin{array}{l}\text { Product } \\
\text { Quality }\end{array}$} & 0.70 & 0.51 & 0.26 & \multirow{3}{*}{1.51} & \multirow{3}{*}{0.55} \\
\hline KP2 & & 0.83 & 0.30 & 0.69 & & \\
\hline KP3 & & 0.75 & 0.43 & 0.56 & & \\
\hline KS1 & \multirow{4}{*}{$\begin{array}{l}\text { Service } \\
\text { Quality }\end{array}$} & 0.77 & 0.41 & 0.59 & \multirow{4}{*}{2.73} & \multirow{4}{*}{0.68} \\
\hline KS2 & & 0.81 & 0.34 & 0.66 & & \\
\hline KS3 & & 0.84 & 0.30 & 0.71 & & \\
\hline KS4 & & 0.88 & 0.23 & 0.77 & & \\
\hline KLF1 & \multirow{3}{*}{$\begin{array}{c}\text { Physical } \\
\text { Environment } \\
\text { Quality }\end{array}$} & 0.69 & 0.53 & 0.48 & \multirow{3}{*}{1.72} & \multirow{3}{*}{0.57} \\
\hline KLF2 & & 0.79 & 0.38 & 0.62 & & \\
\hline KLF3 & & 0.79 & 0.38 & 0.62 & & \\
\hline KPP1 & \multirow{3}{*}{$\begin{array}{l}\text { Customer } \\
\text { Satisfaction }\end{array}$} & 0.74 & 0.45 & 0.55 & \multirow{3}{*}{2.01} & \multirow{3}{*}{0.67} \\
\hline KPP2 & & 0.84 & 0.29 & 0.71 & & \\
\hline KPP3 & & 0.87 & 0.24 & 0.76 & & \\
\hline LP1 & \multirow{3}{*}{$\begin{array}{l}\text { Customer } \\
\text { Loyalty }\end{array}$} & 0.80 & 0.36 & 0.64 & \multirow{3}{*}{1.64} & \multirow{3}{*}{0.55} \\
\hline LP2 & & 0.83 & 0.31 & 0.69 & & \\
\hline LP3 & & 0.56 & 0.69 & 0.31 & & \\
\hline H1 & \multirow{3}{*}{ Happiness } & 0.91 & 0.18 & 0.83 & \multirow{3}{*}{1.87} & \multirow{3}{*}{0.62} \\
\hline H2 & & 0.75 & 0.44 & 0.56 & & \\
\hline H3 & & 0.69 & 0.52 & 0.48 & & \\
\hline K1 & \multirow{4}{*}{ Trust } & 0.96 & 0.08 & 0.92 & \multirow{4}{*}{3.63} & \multirow{4}{*}{0.91} \\
\hline K2 & & 0.95 & 0.09 & 0.90 & & \\
\hline K3 & & 0.97 & 0.06 & 0.94 & & \\
\hline K4 & & 0.93 & 0.13 & 0.86 & & \\
\hline
\end{tabular}

Source: SEM Lisrel 
The result of structural test analysis is by seeing $R^{2}$ score. $R^{2}$ score in every equivalent shows how far an independent variable is capable of explaining the dependent variable. In the first analysis, 74\% variant of PP (perceived price) can be explained by KP variable (product quality), while the rest of $26 \%$ can be explained by other variables that are excluded in this research. From the second analysis, 56\% variant of PP (perceived price) can be explained by KS variable (service quality) while the rest $44 \%$ can be explained by other variables are excluded from this. From the third analysis, 62\% variant of PP (perceived price) can be explained by KLF (physical environment quality), while the rest of $38 \%$ can be explained by other variables excluded in this research. The fourth analysis result, $97 \%$ variants from KP (product quality), KS (service quality) and KLF (physical environment quality) and PP (perceived price), can be explained by KPP variable (customer satisfaction) while the rest $3 \%$ can be explained by other variables that are not included in this research. The fifth analysis, 96\% variant KPP (customer satisfaction) and KLPD (trust) and can be explained by LP variables (customer loyalty) while the rest $4 \%$ can be explained by other variables that are not included in this research, and the last analysis, 75\% variant from KPP (customer satisfaction) can be explained by variable $H$ (happiness) while the rest of $25 \%$ can be explained by other variables that are not included in this research.

\section{Table 5 | Structural equation}

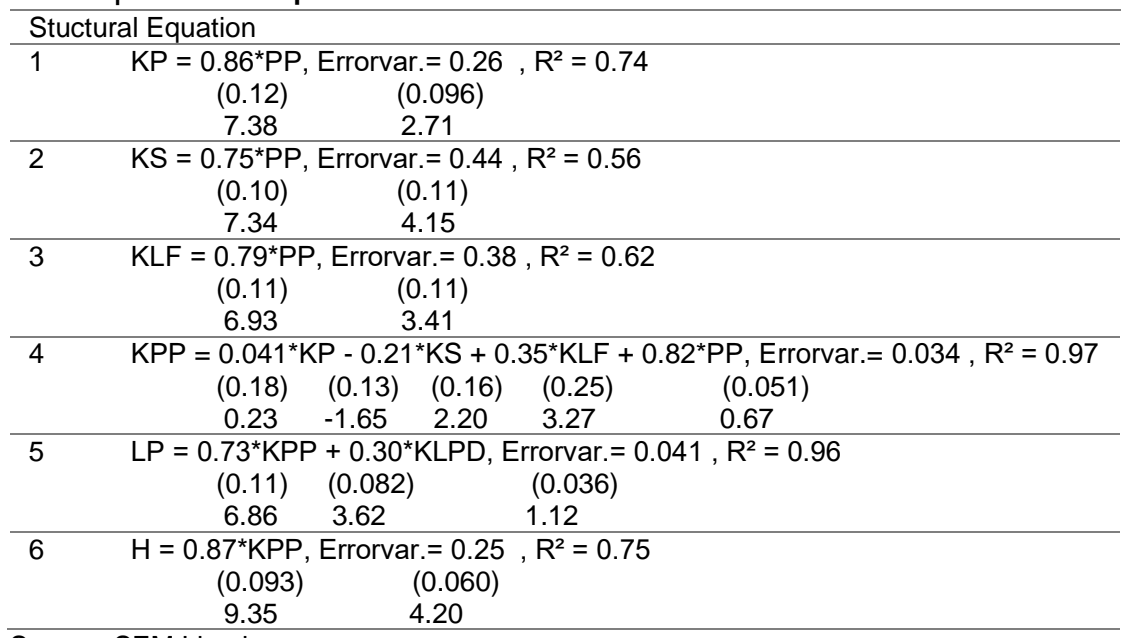

\section{Source: SEM Lisrel}

To find out the suitability of the research model, that is by looking at the output on SEM-Lisrel in the Goodness of Fit section. The results show that several indicators have a good fit (ChiSquare, RMSEA, ECVI, AIC and CAIC, Fit Index), then marginal fit (Goodness of Fit), and poor fit (Critical $\mathrm{N})$. 
Table 6 | Goodness of fit

\begin{tabular}{|c|c|c|c|}
\hline Group & Indicator & Value & Description \\
\hline \multirow{4}{*}{1} & Degree of Freedom & 267 & \multirow{4}{*}{ Good Fit } \\
\hline & Chi Square & 424.18 & \\
\hline & NCP & 157.18 & \\
\hline & Confidence Interval & $105.02 ; 217.27$ & \\
\hline \multirow{3}{*}{2} & RMSEA & 0.068 & \multirow{3}{*}{ Good Fit } \\
\hline & Confidence Interval & $0.055 ; 0.079$ & \\
\hline & P Value & 0.011 & \\
\hline \multirow{4}{*}{3} & ECVI Model & 4.59 & \multirow{4}{*}{ Good Fit } \\
\hline & ECVI Saturated & 5.44 & \\
\hline & ECVI Independence & 84.34 & \\
\hline & Confidence Interval & $4.19 ; 5.06$ & \\
\hline \multirow{6}{*}{4} & AIC Model & 592.18 & \multirow{6}{*}{ Good Fit } \\
\hline & AIC Saturated & 702 & \\
\hline & AIC Independence & 10980.73 & \\
\hline & CAIC Model & 917.06 & \\
\hline & CAIC Saturated & 2059.50 & \\
\hline & CAIC Independence & 10890.73 & \\
\hline \multirow{6}{*}{5} & $\mathrm{NFI}$ & 0.96 & \multirow{6}{*}{ Good Fit } \\
\hline & CFI & 0.98 & \\
\hline & NNFI & 0.98 & \\
\hline & IFI & 0.98 & \\
\hline & $\mathrm{RFI}$ & 0.95 & \\
\hline & PNFI & 0.79 & \\
\hline 6 & Critical N & 92.72 & Poor Fit \\
\hline \multirow{4}{*}{7} & GFI & 0.80 & \multirow{4}{*}{ Marginal Fit } \\
\hline & Standardised RMR & 0.060 & \\
\hline & AGFI & 0.73 & \\
\hline & PGFI & 0.61 & \\
\hline
\end{tabular}

Source: SEM Lisrel

To confirm whether the data support or not support the hypothesis by looking at the t value on the path diagram t-value in SEM-Lisrel. Based on the results of the study, most of the data we obtained have supported the hypothesis, namely the hypotheses $1,4,5,6,7,8 \mathrm{a}$, $8 \mathrm{~b}$, and 9 because the t-value in the hypothesis is above 1.96. while for hypotheses 2 and 3 , the data do not support because the t-value is below 1.96 . 


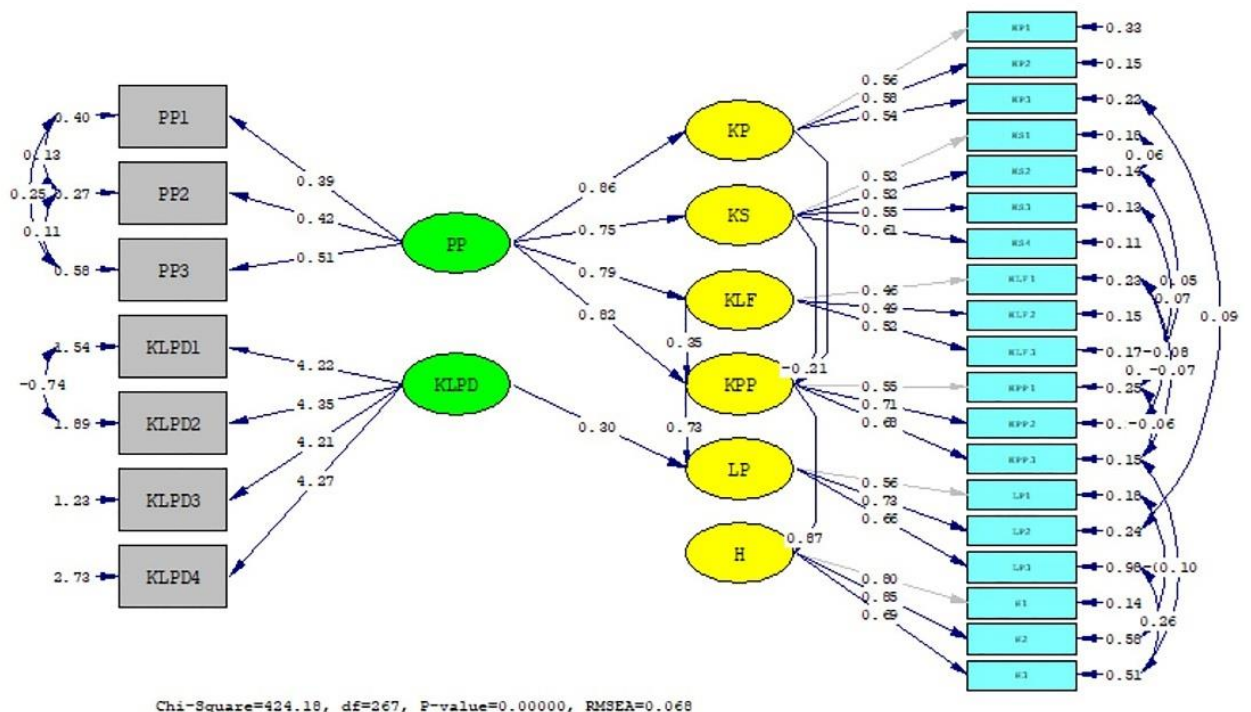

Note: PP (perceived price), KP (product quality), KS (service quality), KLF (physical environment quality), KPP (customer satisfaction), LP (customer loyalty), H (Happiness). Moderating variable: KLPD (trust) Source: SEM Lisrel 
Based on the diagram above, the results of the hypothesis test are:

Table 7 | The summary of hypotheses results

\begin{tabular}{clccc}
\hline \multicolumn{1}{c}{ Hypotheses } & T-Value & Description \\
\hline H1 & $\begin{array}{l}\text { Perceived price has a positive influence on } \\
\text { customer satisfaction. }\end{array}$ & 3.27 & Support \\
\hline H2 & $\begin{array}{l}\text { Product quality has a positive influence on } \\
\text { customer satisfaction. }\end{array}$ & 0.23 & Not support \\
\hline H3 & $\begin{array}{l}\text { Service quality has a positive influence on } \\
\text { customer satisfaction. }\end{array}$ & -1.65 & Not support \\
\hline $\mathbf{H 4}$ & $\begin{array}{l}\text { Physical environment quality has a positive } \\
\text { influence on customer satisfaction. }\end{array}$ & 2.20 & Support \\
\hline $\mathbf{H 5}$ & $\begin{array}{l}\text { Perceived price has a positive influence on } \\
\text { product quality. }\end{array}$ & 7.38 & Support \\
\hline $\mathbf{H 6}$ & $\begin{array}{l}\text { Perceived price has positive influence on service } \\
\text { quality. }\end{array}$ & 7.34 & Support \\
\hline $\mathbf{H 7}$ & $\begin{array}{l}\text { Perceived price has positive influence on physical } \\
\text { environment quality }\end{array}$ & 6.93 & Support \\
\hline $\mathbf{H 8 a}$ & $\begin{array}{l}\text { Customer satisfaction has positive influence on } \\
\text { customer loyalty. }\end{array}$ & 6.86 & Support \\
\hline $\mathbf{H 8 b}$ & $\begin{array}{l}\text { Trust moderates the relation between customer } \\
\text { satisfaction and customer loyalty. }\end{array}$ & 3.62 & Support \\
\hline $\mathbf{H 9}$ & $\begin{array}{l}\text { Customer satisfaction has positive influence on } \\
\text { happiness. }\end{array}$ & 9.35 & Support \\
\hline
\end{tabular}

Source: SEM Lisrel

\section{Discussion}

This study identifies the determinants of customer satisfaction on loyalty and happiness at international fast-food restaurants in Indonesia. The findings show that customer satisfaction with loyalty and happiness is significantly influenced by the quality of the physical environment, perceived price, and trust. Meanwhile, product quality and service quality do not affect customer satisfaction. First, perceived price positively influences pada customer satisfaction. In this research, it is found that satisfaction on customers of fast-food restaurants feels sensitive to perceived price. The customer will feel the price based on what they see and evaluate whether it is expensive or cheap by comparing other brands without trying the product first. Customers will feel sensitive to the increase or decrease or price because they remember and compare the previous transaction. The customer will feel satisfied if the product is worth the price. Therefore, it can be seen that perceived price has positive influences on customer satisfaction. This finding is in concordance with the previous research (Msallam, 2015; Dalati \& Al Hamwi, 2016).

Second, the quality product does not have any influence on customer satisfaction. The customer will not satisfy if the product has an almost a similar concept of taste or design to other brands. Customers will never feel satisfied if a brand can't display consistent flavour products from time to time, they will wait for a new menu or innovation of a brand because customer satisfaction is followed by the basic human nature that never feels satisfied and 
always want something better. Innovation and product display changes that have been designed and sold by the brand manager cannot necessarily make the customer satisfied because they may not be suitable for what the customers want. However, if innovation and the changes of the product are done because of the demand from the customers, then it can have a strong customer satisfaction with string booster power of demand and offer. This finding follows the research that is previously done that product quality has a negative influence on customer satisfaction (Biong, 1993; Tešanović et al., 2018).

Third, service quality does not affect customer satisfaction. This is in line with several previous studies (Athiyaman, 1997; Ladhari et al., 2008; Angelova \& Zekiri, 2011; Tešanović et al., 2018). Friendly and good service is important in service in various types of restaurants because one of the reasons consumers buy these foods is to want to get a different experience from eating at home. However, if the service obtained is not under the needs and desires of the customer, it can trigger customer dissatisfaction. In this study, our respondents did not consider the quality of service they received. They are more likely to pay attention to the situation of the physical environment and the prices they spend when enjoying food or drinks from the restaurant. Currently, most restaurant customers are more concerned with the physical condition of the restaurant in addition to price, product quality, and service quality. This may be because there are other factors outside our study that influence their behaviour in determining their level of satisfaction.

Fourth, the quality of the physical environment affects customer satisfaction. These findings have similarities with previous studies (Bilgihan et al., 2018; Zhang et al., 2019). Currently, customers prefer fast-food restaurants that have a physical, aesthetic, modern character and a high level of cleanliness. This is because many customers like to take photos of themselves while doing certain activities, which will then be used as personal documents or shared with the wider community through social media. The more attractive the physical environment offered, the higher the customer satisfaction received.

Fifth, the perception of price affects the quality of the product. Prices that match the quality of the product can satisfy customers. In the context of a restaurant, customers will pay extra for a particular menu because they perceive it to be of high quality. From the customer's point of view, price is the basis for assessing the quality of food on several menus offered by restaurants. The prices listed on each menu are taken into consideration by customers to assess the quality whether this is appropriate or not. Price can be a measure of the quality of the product. In this study, food quality can be influenced by price perceptions by customers. The results of this study follow previous studies, which also proved that price perception has a positive effect on product quality (Hanaysha, 2016; Zhong \& Moon, 2020).

Sixth, the perception of price affects the quality of service. Restaurant customers' perceptions of prices can lead to high expectations for the quality of the restaurant, one of which is service quality. They assume that the higher the price, the better the quality of the product or service they receive. In this case, the customer's perception of the price of a fastfood restaurant is closely related to the quality of service. The restaurant will try as much as possible to provide the best service according to the price charged to the customer so that the customer has a good assessment of the restaurant. The finding is in line with the study by Ryu et al. (2012) and Yi et al. (2018). 
Seventh, perception of price affects the quality of the physical environment, and this is confirmed by a study by Ryu \& Han (2010) and Yi et al. (2018). As before, price perceptions can also play a role in determining the quality of the physical environment. In the context of a restaurant, the appearance of the physical environment will be adjusted to the price level they listed. They will make sure the physical environment of the restaurant is as attractive and good as possible so that customers can accept the prices given to them. Generally, customers will immediately judge the suitability of the prices issued by the physical condition of the restaurant. If deemed appropriate, customers will give a good rating of the restaurant and will probably make the restaurant their favourite restaurant and will not care how high the price they will spend.

Eighth, customer satisfaction affects customer loyalty. Loyalty is created through a long and simultaneous process that is implemented in customer relationships. One of them can be built by customer satisfaction. In this study, satisfied restaurant customers will always remember the experience they got from the restaurant. This makes them want to always come back to the same restaurant without having to compare it again with other restaurants. Of course, this restaurant is their main choice when they want to eat fast food, and they will be loyal to the fast-food restaurant. This finding was supported by previous research (e.g. Bowen \& Chen, 2001).

Ninth, trust can moderate customer satisfaction on customer loyalty. The trust that customers feel is one part of customer satisfaction, and this can create their loyalty. Customer trust in a particular product or service will be able to build their desire to be loyal to that product or service. If that loyalty has been built in the hearts of customers, it will be easy for a business to get loyalty from them. By business in general, restaurants will also easily get customer loyalty if the customer already has a sense of trust in the restaurant. High customer trust in fast food restaurants can make them always make the restaurant their main choice when they want fast food, without the need to look for other fast-food restaurants. Altamore et al. (2018) and Zhong and Moon (2020) also prove that trust has a positive effect on customer loyalty.

Finally, customer satisfaction affects happiness. This is in line with previous studies which state that customer satisfaction has a positive effect on happiness (Sweeney et al., 2015; Altamore et al., 2018). Generally, feelings of happiness can be created if what they get is following their expectations and desires. In this study, the expectations, desires, and needs of customers that are successfully met by the restaurant can certainly create satisfaction which will lead to happiness for the customer. Satisfied restaurant customers will have their own happiness, and of course, this will be very beneficial for both parties. Happy customers will make them always remember the restaurant and be happy to promote it to others. This will benefit the restaurant.

\section{Implications}

This study has several managerial implications that can be used to increase customer satisfaction and loyalty in fast food restaurants, namely by considering the quality of the physical environment, building trust, and customer views on the price given. Currently, the prevailing trend in Indonesian society is to prefer and use various products or services belonging to other countries, including consuming food or beverage products. In addition, the trend of sharing their daily activities with the wider community through photos on various 
online social media also makes them compete to build a good and unique image for various purposes, such as for endorsements, work, adding friends, or just for personal enjoyment. For this reason, many foreign products have emerged that have successfully built their business in Indonesia, one of which is in the culinary field.

International fast-food restaurants such as KFC, McD, and Pizza Hut are very popular here. Even many local producers are starting to follow the concept of the restaurant. The image of the International fast-food restaurants that we mentioned earlier is very good in the eyes of the Indonesian people. Until now, anyone who can eat at the restaurant is considered classy and able to keep up with the times. Most Indonesians also often compare prices with the products or services they receive. Often this is also used as material or content to be shared on their social media accounts, which can indirectly promote or bring down the image of a brand on certain products or services. Price compatibility is also an important thing that must be considered because restaurant customers will use price as a basis for assessing the quality of a restaurant. If they feel worthy, they will feel satisfied, and this, of course, will also lead to loyalty and happiness for customers.

The right pricing strategy will greatly benefit both parties, not only for the benefit of businessmen but also for consumers. A good pricing strategy implemented by businessmen in their business will allow them to maintain the continuity of the business and provide opportunities for the business to compete and develop. This happens because with the right price, customers will be satisfied and loyal, so they will always support and participate voluntarily to keep the business running well.

The results of this study can also be used in developing countries that have the same respondent criteria as Indonesia. This research can be used as a reference for researchers who also want to research the same thing on various types of products or services belonging to other countries such as fast-food restaurants and others that have succeeded in growing rapidly in our country. That way, producers or businesspeople who want to expand their business in foreign countries or want to build their business in their own country can take the knowledge gained from this research and apply it to their business to be able to survive and compete in the business world well.

\section{Future research and limitations}

There are still some limitations that can be corrected by further researchers; first, this study does not distinguish between respondents who eat at the place and those who order food through delivery services, so there is a possibility that the research results are less accurate because there are several statements in the questionnaire that do not match the respondents. For further research, it is expected to distinguish or focus on one type of customer, whether it is a customer who dine-in or a customer who goes through a delivery service. Second, this research was conducted online, so it is possible that the answers given by respondents were not correct for several reasons, such as not reading the statements carefully and spending a lot of time filling out the questionnaire. So, it is hoped that further research will be carried out by distributing research questionnaires directly. Third, this study did not compare with local fast-food restaurants, so some of the previously assumed factors did not have an important influence on customer satisfaction and loyalty. In the future, it is expected to compare with local fast-food restaurants or products and services owned by the state. 


\section{Conclusion}

Our findings show that perceived price has a positive effect on product quality, service quality, physical environment quality, and customer satisfaction. However, product quality and service quality do not affect customer satisfaction. Furthermore, customer satisfaction plays an active role in determining the level of customer loyalty and happiness. Then, trust can moderate the relationship between customer satisfaction and customer loyalty. To build a fast-food restaurant business, you must apply the right price strategy in addition to other supporting factors because with the implementation of the right price strategy, it will be very easy to get customer satisfaction which will eventually lead to their loyalty. That way, the restaurant will continue to develop and grow amid rapid global competition, especially in the culinary field.

\section{References}

Al-msallam, S. (2015). Customer Satisfaction and Brand Loyalty in the Hotel Industry. International Journal of Management Sciences and Business Research, 9(4), 1-13.

https://doi.org/10.5281/zenodo.3461457.

Alkhurshan, M., \& Rjoub, H. (2020). The scope of an integrated analysis of trust, switching barriers, customer satisfaction, and loyalty. Journal of Competitiveness, 12(2), 5-21.

https://doi.org/10.7441/joc.2020.02.01.

Altamore, L., Ingrassia, M., Chironi, S., Columba, P., Sortino, G., Vukadin, A., \& Bacarella, S. (2018). Pasta experience: Eating with the five senses-A pilot study, AIMS Agriculture and Food, 3(4), 493-520. https://doi.org/10.3934/agrfood.2018.4.493.

Bilgihan, A., Seo, S., \& Choi, J. (2018). Identifying restaurant satisfiers and dissatisfiers: Suggestions from online reviews. Journal of Hospitality Marketing and Management, 27(5), 601-625. https://doi.org/10.1080/19368623.2018.1396275.

Cuesta-Valiño, P., Gutiérrez-Rodríguez, P., \& Loranca-Valle, C. (2021). Sustainable management of sports federations: The indirect effects of perceived service on member's loyalty. Sustainability (Switzerland), 13(2), 1-24. https://doi.org/10.3390/su13020458.

Dalati, S., \& Al Hamwi, S. E. (2016). Sustainable development in higher education through service quality and price fairness: empirical evidence from private universities in Syria. Entrepreneurship and Sustainability Issues, 4(1), 25.

Elizar, C., Indrawati, R., \& Syah, T. Y. R. (2020). Service Quality, Customer Satisfaction, Customer Trust, and Customer Loyalty in Service of Paediatric Polyclinic Over Private H Hospital of East Jakarta, Indonesia. Journal of Multidisciplinary Academic, 4(2), 105-111.

Fandos-Roig, J. C., Sánchez-García, J., Tena-Monferrer, S., \& Callarisa-Fiol, L. J. (2021). Does CSR help to retain customers in a service company?. Sustainability, 13(1), 300. https://doi.org/10.3390/su13010300.

Gong, T., \& Yi, Y. (2018). The effect of service quality on customer satisfaction, loyalty, and happiness in five Asian countries. Psychology and Marketing, 35(6), 427-442.

https://doi.org/10.1002/mar.21096.

Hair J. F., Black, W. C., Babin, B. J, \& Anderson, R. E. (2010). Multivariate Data Analysis. Pearson.

Hair J. F., Black, W. C., Babin, B. J, \& Anderson, R. E. (2018) Multivariate Data Analysis. 8th edn. Annabel Ainscow. https://doi.org/10.1002/9781119409137.ch4.

Hamzah, M. L., Purwati, A. A., Jamal, A., \& Rizki, M. (2021). An Analysis of Customer Satisfaction and 
Loyalty of Online Transportation System in Pekanbaru, Indonesia. In IOP Conference Series: Earth and Environmental Science (Vol. 704, No. 1, p. 012029). IOP Publishing. https://doi.org/10.1088/1755-1315/704/1/012029.

Han, H., \& Kim, W. (2009). Outcomes of relational benefits: Restaurant customers' perspective. Journal of Travel and Tourism Marketing, 26(8), 820-835. https://doi.org/10.1080/10548400903356236.

Hanaysha, J. (2016). Testing the effects of food quality, price fairness, and physical environment on customer satisfaction in fast food restaurant industry. Journal of Asian Business Strategy, 6(2), 31-40. https://doi.org/10.18488/journal.1006/2016.6.2/1006.2.31.40.

Hu, L. T., \& Bentler, P. M. (1999). Cutoff criteria for fit indexes in covariance structure analysis: Conventional criteria versus new alternatives. Structural Equation Modeling: A Multidisciplinary Journal, 6(1), 1-55. https://doi.org/10.1080/10705519909540118.

Jang, S. C. (Shawn), \& Namkung, Y. (2009). Perceived quality, emotions, and behavioral intentions: Application of an extended Mehrabian-Russell model to restaurants. Journal of Business Research, 62(4), 451-460. https://doi.org/10.1016/j.jbusres.2008.01.038.

Kamrul Islam Shaon, S. M., \& Rahman, H. (2015). A Theoretical Review of CRM Effects on Customer Satisfaction and Loyalty. Central European Business Review, 4(1), 23-36. https://doi.org/10.18267/j.cebr.108.

Lai, P. (2018). Research methodology for novelty technology. Journal of Information Systems and Technology Management, 15. https://doi.org/10.4301/s1807-1775201815010.

Möslein-Tröppner, B., Stros, M., \& Říha, D. (2020). Customer loyalty-related marketing measures in fashion markets. Central European Business Review, 9(1), 43-55.

https://doi.org/10.18267/j.cebr.228.

Mulyo, J. H., Rohmah, F., Perwitasari, H., \& Nasir, M. A. (2021, February). The Service Quality of Kampoeng Kopi Banaran Agrotourism, Central Java Province, Indonesia. In IOP Conference Series: Earth and Environmental Science (Vol. 662, No. 1, p. 012003). IOP Publishing. https://doi.org/10.1088/1755-1315/662/1/012003.

Paramartha, A., \& Syah, T. Y. R. (2020). The Influence of Customer Satisfaction on Customer Loyalty and Marketing Organization Performance Over Outdoor Advertising Companies. Journal of Multidisciplinary Academic, 4(4), 234-241.

Qin, H., \& Prybutok, V. R. (2009). Service quality, customer satisfaction, and behavioral intentions in fast-food restaurants. International Journal of Quality and Service Sciences, 1(1), 78-95. https://doi.org/10.1108/17566690910945886.

Rahman, H. (2013). Customer Satisfaction and Loyalty: A Case Study from the Banking Sector. Central European Business Review, 2(4), 15-23. https://doi.org/10.18267/j.cebr.60.

Rothenberger, S. (2015). Fairness through transparency: The influence of price transparency on consumer perceptions of price fairness. Univ. Libre de Bruxelles, Solvay Brussels School of Economics and Management, Centre Emile Bernheim, pp. 1-32.

Ryu, K., \& Han, H. (2010). Influence of the Quality of Food, Service, and Physical Environment on Customer Satisfaction and Behavioral Intention in Quick-Casual Restaurants: Moderating Role of Perceived Price. Journal of Hospitality and Tourism Research, 34(3), 310-329. https://doi.org/10.1177/1096348009350624.

Ryu, K., Hye-Rin, L., \& Kim, W. G. (2012). The influence of the quality of the physical environment, food, and service on restaurant image, customer perceived value, customer satisfaction, and behavioral intentions. International Journal of Contemporary Hospitality Management, 24(2), 175-199. https://doi.org/10.1108/09596111211206141. 
Sarmiento-Guede, J. R., Antonovica, A., \& Antolín-Prieto, R. (2021). The green image in the spanish hotel sector: Analysis of its consequences from a relational perspective. Sustainability (Switzerland), 13(9), 1-17. https://doi.org/10.3390/su13094734.

Sweeney, J. C., Danaher, T. S., \& McColl-Kennedy, J. R. (2015). Customer Effort in Value Cocreation Activities: Improving Quality of Life and Behavioral Intentions of Health Care Customers. Journal of Service Research, 18(3), 318-335. https://doi.org/10.1177/1094670515572128.

Syah, T. Y. R., \& Wijoyo, C. K. (2021). Service Quality and Customer Satisfaction on WOM a Private Hospital in Indonesia. JMMR (Jurnal Medicoeticolegal dan Manajemen Rumah Sakit), 10(1), p. 22-34. https://doi.org/10.18196/jmmr.v10i1.10141.

Yi, S., Zhao, J., \& Joung, H. W. (2018). Influence of price and brand image on restaurant customers' restaurant selection attribute. Journal of Foodservice Business Research, 21(2), 200-217. https://doi.org/10.1080/15378020.2017.1368808.

Yu, H., \& Fang, W. (2009). Relative impacts from product quality, service quality, and experience quality on customer perceived value and intention to shop for the coffee shop market. Total Quality Management and Business Excellence, 20(11), 1273-1285. https://doi.org/10.1080/14783360802351587.

Zhang, T., Chen, J., \& Hu, B. (2019). Authenticity, quality, and loyalty: Local food and sustainable tourism experience, Sustainability (Switzerland), 11(12), 1-19. https://doi.org/10.3390/su10023437.

Zhong, Y., \& Moon, H. C. (2020). What Drives Customer Satisfaction, Loyalty, and Happiness in FastFood Restaurants in China. Perceived Price, Service Quality, Food Quality, Physical Environment Quality, Moderating Role of Gender. Foods, 9(4), 460.

Zhuang, K., \& Jiang, Y. (2016). An analysis of the development of the Chinese fast food industry. Journal of Asian Business Strategy, 6(5), 85-100.

https://doi.org/10.18488/journal.1006/2016.6.5/1006.5.85.100.

\section{Appendix}

\begin{tabular}{cl}
\hline No & Statement \\
\hline $\mathbf{1}$ & Perceived Price \\
\hline $\mathbf{2}$ & Bhe price of KFC/McD/Pizza Hut is reasonable \\
\hline $\mathbf{3}$ & The price of KFC/McD/Pizza Hut is affordable \\
\hline $\mathbf{1}$ & I recognise that the quality of food is good in KFC/McD/Pizza Hut. \\
\hline $\mathbf{2}$ & I recognise that the taste of food is good in KFC/McD/Pizza Hut. \\
\hline $\mathbf{3}$ & I recognise that the purity of food is good in KFC/McD/Pizza Hut. \\
\hline $\mathbf{2}$ & Service Quality \\
\hline
\end{tabular}


$3 \mathrm{KFC/McD/Pizza} \mathrm{Hut} \mathrm{staff} \mathrm{serve} \mathrm{quickly} \mathrm{and} \mathrm{promptly}$

4 I feel comfortable with KFC/McD/Pizza Hut staff members' service.

\section{Physical Environment Quality}

$1 \mathrm{KFC} / \mathrm{McD} / \mathrm{Pizza}$ Hut environment is clean

2 The lighting in KFC/McD/Pizza Hut is comfortable

3 The temperature in KFC/McD/Pizza Hut is comfortable

\section{Customer Satisfaction}

1 The overall experience of KFC/McD/Pizza Hut is satisfying

2 I think my decision to visit KFC/McD/Pizza Hut was a wise one

$3 \mathrm{KFC/McD/Pizza} \mathrm{Hut} \mathrm{meets} \mathrm{most} \mathrm{of} \mathrm{my} \mathrm{expectations}$

\section{Customer Loyality}

1 I will continue to use KFC/McD/Pizza Hut services if any

2 I will recommend others to use KFC/McD/Pizza Hut service

3 Even if close friends recommended another service, my preference for $\mathrm{KFC/McD/Pizza} \mathrm{Hut} \mathrm{service} \mathrm{would} \mathrm{not} \mathrm{change}$

\section{Happiness}

1 I think visiting KFC/McD/Pizza Hut will contribute to customer happiness

2 By visiting KFC/McD/Pizza Hut, customers' quality of life will be improved

$3 \mathrm{KFC} / \mathrm{McD} /$ Pizza Hut provides a happy and enjoyable dining experience for my family and friends

\section{Trust}

1 Based on my experience, I know KFC/McD/Pizza Hut service provider is honest

2 Based on my experience, I know KFC/McD/Pizza Hut service provider cares about customers

3 Based on my experience, I know KFC/McD/Pizza Hut service provider is trustworthy

4 Based on my experience, I know KFC/McD/Pizza Hut service provider is reliable

Source: authors

The research article passed the review process. | Received: September 13, 2021; Revised: December 22,2021; Accepted: January 19, 2022; Pre-published online: March 7, 2022; Published in the regular issue: September 19, 2022. 